\title{
JOURNAL.RU
}

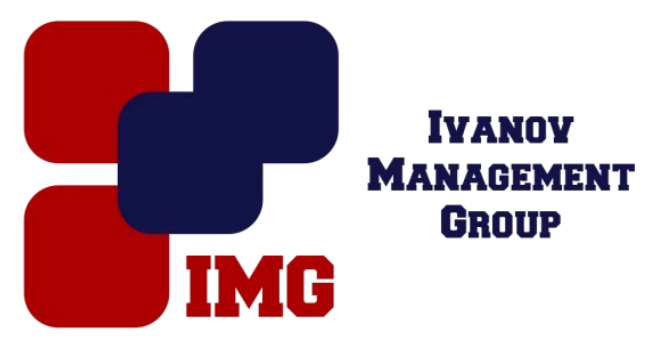

Городецкая Е.А., Городецкий Ю.К. Белорусский государственный аграрный технический университет Минск, Беларусь

doi: 10.18411/lj-30-11-2016-4-03

idsp 000001:lj-30-11-2016-4-03

\section{Повышение агрономических свойств семян с.-х. растений после электрофизического воздействия}

\section{Аннотация}

Приведена информация о важности энергетических показателей семян всхожести и энергии прорастания, показано преимущество диэлектрических сепараторов на стадии выделения семян категории «экстра» и методов по предпосевной доработке семян.

Ключевые слова: семена с.-х. растений, всхожесть, энергия прорастания, агрономические качества, диэлектрическая сепарация, фракции семян гарантированного качества

\section{Alena Gorodecka, Yuzef Gorodecki}

Improving agronomic properties of seeds of agricultural plants after the electrophysical exposure

Information over is brought about importance of power indexes of seed germination and energy of germination, advantage of dielectric separators is shown on the stage of selection of seed to the category 'premium' and methods on the preseed revision of seed.

\section{Введение}

На качество сельскохозяйственной продукции оказывают влияние многие факторы: качество семян, сроки посадки, уход за посевами, сбор урожая, его сохранение и доставка потребителю. Важны все эти стадии и многие другие среди них, но качество семян часто определяет не только нагрузку на высевающие аппараты, но и насколько растение будет сильным, а его плод здоровым и лежким. Современные технологии промышленного возделывания уже предполагают выращивание, к примеру, сахарной свеклы без затрат ручного труда за счет посева на конечную густоту растений. И здесь большое значение имеет качество подготовленных семян. На сегодня отечественными учеными 
разработаны различные технологии предпосевной обработки семян, что обеспечивает производителей высококачественным посевным материалом, однако и его качество не всегда соответствует растущим потребностям производства. Поэтому применение дополнительных методов обработки семян с целью их стимулирования является одним из резервов повышения их посевных качеств и урожайных свойств [1].

\section{Общая часть}

Электросепарация семян известна как традиционный способ получения гомогенных фракций элитного посевного материала для последующего интенсивного возделывания с.-х. культур по промышленным технологиям. При оценке фракций семян, получаемых при разделении на диэлектрическом сепараторе лабораторном (СДЛ-1) кафедры электротехнологии УО «БГАТУ» мы руководствовались стандартными показателями: всхожесть и энергия прорастания семян [2-4]. СДЛ-1 обладает эффективной конструкцией, практической и научной новизной, реализует конкурентноспособную технологию, разделяя семенной ворох на фракции заданного качества с учетом электрических свойств частиц и семян.

Метод диэлектрического разделения с реализацией принципа суперпозиции сил различной физической природы и использования, прежде всего, пондеромоторной силы, показал высокую эффективность на получении чистой соевой шелухи (напряжение 1,0-2,0 кВ) и был использован при ее получении в технологии производства пероксидазы.

Методика проведения исследований

Для исследований были взяты одинаковые навески семян стандартной (для хранения) влажности 12-14\%. Контроль оставляли, а навески загружали в бункер сепаратора и равномерно подавали на вращающийся рабочий орган с бифилярной обмоткой и установленным для данной культуры напряжением. Имеющиеся приемники продуктов разделения в процессе сепарации наполнялись составляющими исходной смеси, затем поддавались взвешиванию, оценке и дальнейшему анализу агрономических показателей. Проращивание семян проводили на увлажненной фильтровальной бумаге в чашках Петри в термостате при температуре +21 оС. Полученные фракции выровненных семян были протестированы [3-4] на всхожесть и энергию прорастания, а часть из них стала исходным материалом для последующих исследований на повышение агрономических показателей посредством радиоволновой и плазменной обработки (осуществленной в ГНУ «Институт физики им. Б.И.Степанова НАН Беларуси»), методика которых описана [5].

\section{Результаты и обсуждение}

Отсепарированные образцы распределялись по фракциям, предварительные лучшие режимы напряжения на рабочем органе для мелкосемянных зеленных культур лежат в диапазоне $0,8-1,0$ кВ без взаимного подсора фракций. Сейчас ведутся исследования по устранению просыпания 
мелких семян в межэлектродный зазор с целью повышения эффективности процесса сепарации и предотвращения потери ценных семян.

Наилучшие фракции пшеницы и ржи получены при рабочих напряжениях СДЛ-1, варьируемых в диапазоне 2,5 - 3,5 кВ, в то время как для люпина оптимальным оказалось напряжение порядка 3,0 кВ. Здесь наблюдали четкое разделение на составляющие исходной смеси и получение чистых семян высокой посевной кондиции.

Анализ результатов показывает, что и некондиционные семена после электрофизической обработки, могут быть использованы для подсевов в случае нехватки семян-экстры. Результаты исследований показывают явное «улучшение» качества семян, которые уже были малопригодны для посева.

\section{Выводы}

Механизмы действия электромагнитных полей, проявляющих свое действие при нахождении семян на рабочем органе СДЛ-1 на растительные объекты являются малоизученными. При относительно высоких уровнях плотности мощности облучающего поля современная теория признает тепловой механизм воздействия. В проведенных нами экспериментах заметный нагрев обрабатываемых семян отсутствовал. В этом случае принято говорить о нетепловом или информационном характере воздействия.

Таким образом, электросепарирование и другие электрофизические воздействия на семена делают возможным получение чистых фракций мелкосемянных культур (лекарственные, пряно-ароматические и красивоцветущие растения), является необходимой и высокоэффективной операцией по подготовке семенной фракции в технологии промышленного производства зерна в интенсивном земледелии; обеспечивает получение семян с высокими посевными качествами и урожайными свойствами. По многим литературным данным прослеживается утверждение о более высоких потребительских качествах и больших сроках хранения продукции из обработанных семян. обусловлена экономией финансовых средств за счет снижения объемов закупки элитных семян и внедрения машинных технологий выращивания и уборки. Следует подчеркнуть экологичность данных воздействий и возможность снижения пестицидного прессинга в агрокультуре. 


\section{Литература}

1. Алексейчук, Г.Н.Алексейчук, Н.А.Ламан Физиологическое качество семян сельскохозяйственных культур и методы его оценки/ Минск, ИООО «Право и экономика». 2005. - 47 с.

2. Hampton J.G. What is Seed Quality? //Seed Science and Technology. -2002.V.30. - P.1-10.

3. Международные правила анализа семян / Пер. с англ. Н.Н.Антошкиной; М.: Колос, 1984. - $310 \mathrm{c}$.

4. Кабашникова Л.Ф. // Способ ранней диагностики эффективности многокомпонентных капсулирующих составов для обработки семян. Методические указания. Минск. 2003. -17 с.

5. Городецкая, Е.А.Городецкая, В.С.Корко, В.В.Ажаронок Стимулирование всхожести семян высокочастотным полем/ Агропанорама, № 2, 2011.- С. 11-13. 